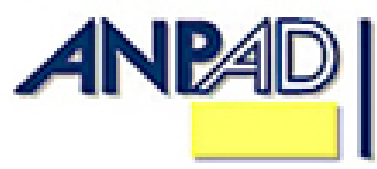

Available online at http://www.anpad.org.br/bar

BAR, Rio de Janeiro, v. 11, n. 2, art. 5, pp. 210-227, Apr./June 2014

\title{
Meanings of Consumption and Abandonment: Understanding Smoking Cessation Symbolism
}




\begin{abstract}
In consumption studies, very little attention has been focused on investigating abandonment and, more specifically, its symbolic dimension. The present study aims to investigate how meanings are created and negotiated through the abandonment of cigarettes. This study used a qualitative methodology to collect and analyze the data generated by one-on-one semi-structured in-depth interviews with 15 Brazilian ex-smokers. Results suggest that abandonment of cigarettes can be offered as a connection, gift, or sacrifice that makes relations special and even magical. As regards abandonment, the present study evidences the interactions and movements of positive and negative meanings related to the consumption and non-consumption of a category. The study proposes a framework that highlights the cooling, decontamination, reinforcement and defensive symbolical movements, thus constructing a tool for analyzing abandonment, offering possible paths of intervention for organizations that are interested in this issue.
\end{abstract}

Key words: abandonment; cigarettes; consumer behavior; tobacco control. 


\section{Introduction}

According to the World Health Organization, tobacco kills nearly six million people a year and thus accounts for one in 10 adult deaths (World Health Organization [WHO], 2013). Giving up smoking benefits smokers' health and increasing the smoking cessation rate can save many lives. Despite important developments in tobacco control, the consumption of tobacco products is increasing globally (WHO, 2013) and US national data for the 1991-2010 period shows no consistent upward trend in the population cessation rate during this two-decade period (Zhu, Lee, Zhuang, Gamst, \& Wolfson, 2012).

In tobacco control studies, several advances have been made in the understanding of smoking cessation, specially the effect of pharmacotherapies and media campaigns (see Zhu et al. 2012 for a recent literature review). However, most of these studies focus on physical or cognitive aspects of smoking behavior.

Marketing and consumer behavior researchers can contribute to these studies by incorporating a perspective that addresses the sociocultural, experiential, symbolic, and ideological aspects of consumption (Arnould \& Thompson, 2005). This approach considers that products are consumed not only because of their functionality but mainly due to their symbolic dimension. Pechmann, Biglan, Grube, and Cody (2012) stress this difference, calling for papers based on ethnographic studies that focus on smoking habits around the world.

In addition, very little attention has been focused by the marketing and consumer behavior area on investigating abandonment and, more specifically, its symbolic dimension. The present study aims to investigate how meanings are created and negotiated through the abandonment of cigarettes. This study used a qualitative methodology to collect and analyze the data generated by one-on-one semistructured in-depth interviews with 15 Brazilian ex-smokers.

\section{Literature Review}

With the aim of investigating the meanings associated with the abandonment of cigarettes the present study articulates two specific fields. The first involves studies developed in the area of tobacco studies that investigated smoking cessation, while the second consists of studies in the marketing and consumer behavior area relating to abandonment.

Over the past 20 years, smoking cessation researchers have investigated different actions involving encouragement and support for the abandonment of this category. Researchers in this area have, for example, studied the impact of pharmacotherapies such as nicotine patches and other forms of nicotine replacement therapy (Cahill, Stead, \& Lancaster, 2011; Hughes, Stead, \& Lancaster, 2007; Stead, Perera, Mant, \& Lancaster, 2008). Recent studies indicate that use of cessation medications has increased substantially in the USA (Shiffman, Brockwell, Pillitteri, \& Gitchell, 2008) and UK (West, DiMarino, Gitchell, \& McNeill, 2005).

The effect of quitline services on smoking cessation indices has also been analyzed by various studies (Anderson \& Zhu, 2007; Miller, Wakefield, \& Roberts, 2003; Sheffer et al., 2010). Recent research has found that quitline use is influenced by promotional efforts (Miller et al., 2003) and state announcements about new secondhand smoke policies or tax increases (Sheffer et al., 2010). Different studies also suggest that inserting a quitline number on cigarette packs along with graphic warning labels, dramatically increases quitline calls (Li \& Grigg, 2009; Miller, Hill, Quester, \& Hiller, 2009; Willemsen, Simons, \& Zeeman, 2002). The positive contribution of new technologies has also been studied by researchers interested in the theme. Cobb and Graham (2006) state that $9 \%$ of all internet users have searched for information on how to quit smoking, but evidence regarding the effectiveness 
of such action is inconclusive (Civljak, Sheikh, Stead, \& Car, 2010; Rabius, Pike, Wiatrek, \& McAlister, 2008). Other researchers (Brendryen \& Kraft, 2008; Brendryen, Drozd, \& Kraft, 2008) also found a positive effect on smoking cessation related to the sending of messages using various means (like email, web pages, text messages, calls).

Other studies have sought to map the importance of health service providers in encouraging cigarette abandonment (Aveyard et al., 2007; Rice \& Stead, 2008). In this context one should highlight the role of doctors and actions such as offering brief advice, prescribing medications and behavioral counseling (Fiore, 2008; Ockene et al., 2007).

According to National Cancer Institute (2008) tobacco cessation is also influenced by paid advertisements and earned media. Their effect is related not only to their ability to motivate smokers to quit, but also to change social norms regarding smoking (Cowling, Modayil, \& Stevens, 2010). In a similar way news coverage conveys the importance of the issue being discussed while framing the public's perception of it (Chapman, 1999; Malone, Boyd, \& Bero, 2000).

More than the effect of the medium, a recent report sought to discuss the effectiveness of different approaches by compiling several studies (National Cancer Institute, 2008). This work highlights that emotional or personal adverts were found to be more effective than humorous adverts in encouraging quitting. It also states that messages on the dangers of secondhand smoke to nonsmokers can motivate smokers to quit just as much as those on the risks to smokers themselves.

Various studies have repeatedly found that higher cigarette prices, usually due to tax increases, can decrease smoking prevalence (Hopkins et al., 2001). Higher prices not only deter non-smokers from starting to smoke (Chaloupka \& Wechsler, 1997), but also lead current smokers to reduce consumption or quit completely (Chaloupka \& Warner, 1999; Scollo, Younie, Wakefield, Freeman, \& Icasiano, 2003). According to Siahpush, Wakefield, Spittal, Durkin and Scollo (2009) and Martire, Mattick, Doran, and Hall (2011) this effect may be greater among low-income smokers.

In the field of marketing and consumer behavior the first analyses of abandonment were only recently performed in the context of anti-consumption studies. Hogg (1998) affirms that abandonment, avoidance and aversion represent different degrees of anti-choice although they overlap to some extent. Anti-choice is related to offers that were actively not chosen because they are seen to be inconsistent or incompatible with a consumer's other choices or preferences (Hogg, 1998).

For Hogg, Banister and Stephenson (2009), aversion is the act of physically and emotionally disentangling oneself from something. This is the clearest expression of disgust, involving more definitive decisions of non-consumption. Avoidance, on the other hand, refers to the act of keeping oneself apart and is more related to the wish to minimize consumption choices that may have undesirable symbolic or cultural associations. Abandonment is the action of giving up something previously consumed and presupposes the existence of a deliberate choice (Hogg, 1998). According to these authors, aversion (expressed as disgust, loathing or repulsion) may generate avoidance and abandonment behaviors. The former tends to precede or appear together with expressions of avoidance and abandonment.

Kleine and Kleine's (2000) suggest that individuals manage facets of their self-concept by discarding certain aspects of their identity as their self-concept evolves. In this process, the abandonment of products and categories may serve as an indicator of new identities and social conditions. Other authors also relate disposition and abandonment behaviors to social transition, that is, changes in the life-cycle or status of individuals (Hogg, Banister, \& Stephenson, 2009; Roster, 2001; Young, 1991). Hogg and Banister (2001) affirm that in order to maintain a positive self-image or at least a normative self-standard - consumers avoid risks, rejecting products, brands or suppliers that are associated with undesirable or negative stereotypes or reference groups.

Recently, Suarez, Chauvel and Casotti (2012) examined the specificities of category abandonment, showing that it is a process rather than a decision or an action circumscribed by a given moment. According to those authors, abandonment may include inertia or procrastination behavior 
(abandoning use without effectively making a decision) and situations where a deliberate choice is made. The authors outline different types of abandonment: when the product is no longer within the consumer's means (concrete problems like lack of money, space, time, comfort, health); when there is a rejection of the product's symbolic aspects and, finally, when there is an ideological and collective motivation that make consumers believe that society should abandon or rethink consumption.

In their study the authors describe abandonment not only as a movement of distancing oneself from negative meanings in order to protect self-esteem (Hogg et al., 2009), but also as one of affirmative differentiation, helping individuals to constitute positive identities through nonconsumption. Suarez et al. (2012) states that those symbolic associations continue to be used, created and manipulated even after abandonment has occurred.

In the field of marketing and consumer behavior the abandonment of consumption is a largely unexplored topic. In the present study, the understanding of smoking cessation can be increased by an analysis that addresses this behavior not only through its physical (for example the effect of medication), cognitive (processing of anti-smoking campaign messages), and instrumental (effectiveness of quitlines, role of health professionals) dimensions, but also though a broader perspective that sees consumption as a cultural phenomenon; i.e. as involving the production of socially-shared meanings.

\section{Method}

This study used a qualitative research design to explore meanings that arise from the abandonment of cigarettes. For data collection I decided to use the widely employed qualitative indepth interview method, considered to be one of the most important in the qualitative arsenal (McCracken, 1988). In addition to more public, conscious and communicational aspects, the interviews sought to capture unconscious aspects related to attitudes and motivations. Thus, one of the resources used by the research was to include projective exercises during the course of the interview. According to Rook (2006), projective techniques are particularly important in research into consumers' emotions, desires and motivations and the meanings attached to and relationships established with products and brands.

The research interviewed a total of 15 ex-smokers who had abandoned consumption during the previous five years. The interviewees were composed of adults between the age of 29 and 63, a group which accounts for most of the country's smokers. Gaskell and Bauer (2002) caution that the number of interviews should be sufficient to evidence diversity of behavior and provide consistency for the concepts developed during the research process. In the present study, the appearance of new categories related to meanings associated with cigarette abandonment was perceived until the carrying out of the sixth interview. However, to ensure replication in categories, replication verification, and ensure the comprehension and completeness of the main concepts presented here, 15 interviews were performed. At this point, the researcher encountered so-called theoretical saturation, where no new insights are obtained, no new themes identified, and no issues arise regarding a data category (Gaskell \& Bauer, 2002; Strauss \& Corbin, 2008). Table 1 sets out the profiles of interviewees.

Table 1

\section{Informant Profile}

\begin{tabular}{lllll}
\hline Pseudonym & Age & Marital Status. & Kids? & Profession \\
\hline Amanda & 36 & Single & No & psychologist \\
Shirley & 54 & Single & No & journalist \\
Nancy & 44 & Married & Yes & journalist \\
Cristiane & 29 & Single & No & economist \\
\hline
\end{tabular}


Table 1 (continued)

\begin{tabular}{lllll}
\hline Pseudonym & Age & Marital Status. & Kids? & Profession \\
Isadora & 57 & Divorced & Yes & psychologist \\
Rose & 48 & Divorced & Yes & lawer \\
Rachel & 42 & Married & Yes & economist \\
Mary & 42 & Single & No & philosopher \\
Marco & 37 & Single & No & computer technician \\
Flávio & 63 & Married & Yes & lawer \\
Priscila & 39 & Married & No & Designer \\
Renata & 42 & Married & Yes & publicist \\
Suzana & 40 & Married & No & jornalist \\
Antony & 60 & Married & Yes & Business consultant \\
Fábio & 40 & Single & No & film-maker \\
\hline
\end{tabular}

All fifteen interviews were recorded, transcribed (around 350 pages of transcribed interviews) and analyzed for deep meanings. Two different analytical processes were used: hermeneutic interpretation (Thompson, Pollio, \& Locander, 1994) and analytical coding (Miles \& Huberman, 1994). The first one guarantees an iterative analysis where the part is interpreted in relation to the whole for the construction of the present study. The analytical process began by reading the whole text through once. This creates a sense of the entire text as it relates to meanings of abandonment. The researcher tried to capture an integrative sense and connections between past, present, and future in informants' stories. Analytical coding, in a complementary way, makes it possible to discover, refine and develop concepts, themes and events which could be codified and inter-related (by confronting interviewee narratives) This comparison enables the researcher to detect subtle differences in the way concepts are presented or how different informants attach diverse meanings to the same event. Some of these codes were suggested by the literature while others were created during the process of analyzing interviews. In the end, the research that led to the present study arrived at a total of 446 primary codes which were refined and classified during the analytical process, constituting some of the theoretical categories that will be proposed in the analysis. The analysis was performed with the support of the Atlas.ti (version 6) program.

\section{The context of research}

Brazil has reduced its smoking rate by about $50 \%$ in the last 20 years, as a result of tobacco control policies, that include strong taxes, marketing restrictions, health warnings, and other tobaccocontrol programs (Levy, Almeida, \& Szklo, 2012). In Brazil, smoking is prohibited in all enclosed public places and the vast majority of enclosed workplaces. Direct advertising through most forms of mass media is prohibited. Tobacco advertising and promotion, apart from the display of the products themselves, is prohibited at points of sale. Additionally, tobacco products must carry graphic health warnings covering 100 percent of the back side and 100 percent of one side of the packages. In a recent research, $47 \%$ of smokers reported that the warning labels on cigarettes made them think about quitting and $31 \%$ said they thought about quitting or planned to quit smoking (Projeto ITC, 2009). However, reducing the prevalence of smoking further is still a challenge, since, in 2011, almost 28 million Brazilians smoked tobacco products, which accounted for $14.8 \%$ of the population (Ministério da Saúde, 2012). 


\section{Findings}

The analysis of the interviews evidenced that consumption and non-consumption are coconstituted, inextricably linked discourses. During the conversations, informants referred to the positive and negative meaning they had experienced in both consumption and abandonment (nonconsumption). In order to gain a deeper understanding of the meanings associated with smoking cessation, the following analysis was based on these dimensions, seeking to map a wide range of actions, through which interviewees created and manipulated meanings, individually and socially.

\section{Abandonment as a movement of distancing oneself from the negative meanings of consumption}

Various informants recounted that their reason for abandoning cigarettes was a wish to distance themselves from the stigma they experienced as smokers. From a social perspective, within the dualist view that characterizes modern thought regarding consumers (Slater, 2002), the abandonment of cigarettes provides a sense of victory of the heroic consumer (rational and sovereign in the definition and meeting of his needs) over the dupe consumer (the irrational slave of desires, a conformist, an idiot seduced by advertising).

Abandonment is presented in the interviews as a declaration of self-control, independence and autonomy on the consumer's part.

"I freed myself, my daily life is much better. I don't need to leave a party because I don't have cigarettes, before going out I don't have to ask everyone to stop at a gas station to buy cigarettes. I am freer now, nowadays I'm an easier person to get along with". (Cristiane, 29 years, economist).

During interviews informants sometimes describe consumption and its consequences as a punishment and emphasize physical illness, inconveniences, limitations and losses caused by the product. Through the control of consumption and finally by effective abandonment, consumers disengage from the worst features that the consumption of the category expresses. Limiting consumption due to specific locations, people (for example, not smoking in front of one's parents), situations and routines (not smoking before breakfast), and even establishing specific schedules (for example, only smoking one cigarette an hour) are examples of actions that help consumers to distance from negative meanings associated with the product and its consumption.

Antony (60 years, business consultant), for example, remembers a remarkable story from the time when he still used to smoke: the day at an airport, after checking-in and going to the departure lounge, that he felt compelled to go out for a smoke, he had to go through all airport control procedures once again. Thus, before abandoning consumption definitively he created a personal rule of abstinence inside planes, even before it was forbidden by law:

"I decided that I was not going to smoke anymore in planes and due to this decision I purchased myself a non-smoker seat. I was completely conditioned, I would get on the plane and instantly feel like a nonsmoker, I would get angered by people that smoked around me. I found myself always complaining. Once I got off the plane the first thing I did was to light a cigarette. But when I was on the plane I had no craving for a cigarette".

Even limited to the duration of a flight, abstinence engendered an important transformation: turning Antony into a non-smoker. He was able to experience not only a state of independence from the product but also the inconvenience it caused to those who did not share his addiction. During these moments he was able to observe consumption from a non-smoker's perspective, thus distancing himself emotionally from the category. This distancing seems to have contributed to exacerbating his perception of the smoker as a kind of social outcast, a feeling that was decisive for his abandonment. 
Rachel (42 years, economist), initially reduced her consumption by removing the stock she kept of the product. She says that, working at home, she began to worry about her excessive consumption. Therefore she began to keep the product outside her office, thus forcing her to go out to get a cigarette: "because if I had them beside me, I would lose control and start chain-smoking". In Flavio's (63 years, lawyer) case, abstinence was practiced through the purchasing method. When he decided to give up smoking he stopped buying packs. So he began to buy single cigarettes: "If you add things up it's much more expensive to buy ten cigarettes at 25 cents each than buying the whole pack. But we reason like this: I didn't buy a pack, I bought a cigarette".

The examples above evidence the expressive and symbolic importance of these actions. Antony, Rachel and Flávio develop a kind of private ritual - a type of expressive and symbolic activity that occur in a episodic sequence and tend to be repeated over time (Rook, 1985). Such activities are performed with inner intensity, as they represent an inconvenience and even financial sacrifice for the consumer. However, in return, informants seem to wish to "declare" their control over their consumption, gradually disengaging themselves from meanings such as addiction, lack of discipline and neglect of one's wellbeing generally associated with product users.

\section{Cooling positive meanings of consumption}

Abandonment represents a break with the order and predictability that cigarettes used to confer on the routine of some interviewees. For various informants, cigarettes serve as a ritual artifact that communicates temporal organization (when to wake up, the beginning or end of the day, after lunch, beginning and end of work, etc.); and different tasks and emotional states (activating, concentrating, relaxing, socializing, etc.). Thus, some informants recounted that giving up cigarettes led to disorientation in relation to scripts and roles performed on a day-to-day basis. Nancy (44 years, journalist), for example, spoke of the difficulty she and her husband had in restoring the moments of intimacy and relaxation they used to experience when sharing a cigarette late at night. Shirley (54 years, journalist) sadly laments the loss of moments of introspection that cigarettes provided her with and affirms that she has "no longer been able to be with herself, always being in a state of movement".

Thus, in order to realize abandonment, consumers need to handle a certain disorientation and related feelings of loss, sadness and nostalgia, evidencing the positive meanings perceived by exconsumers in the category. Remembering the pleasures and benefits that the product provided, lamenting its absence, emphasizing the unique and irreplaceable character of that category and longing to resume consumption, constitute some of the examples found in this research.

Antony (60, business consultant), Fábio (40 years, actor and film-maker), Nancy (44 years, journalist), Mary (42 years, philosopher) are examples of consumers who expressed the abandonment of cigarettes as a kind of death. Antony's account, shown below, exemplifies this symbolic elaboration:

"I used to like smoking a lot. Smoking was a pleasure for me, something that accompanied in all situations. I couldn't work without smoke, think, feel jealous, drink, have a cup of coffee. I'm not going to go through that again. But nowadays, nostalgically, I have fond memories of that time. It's like remembering a friend who has died. It was great while he was alive but he is dead, he's not here anymore".

Antony made a choice not to depend on cigarettes but copes with the losses by remembering this friend with nostalgia. Like mourning rituals those actions seem to communicate to the ex-smoker that, just as the dead cannot come back to life, the experience of consumption also cannot be resumed.

Mourning, in addition to expressing a sense of loss, manifests itself in some cases through feelings of revolt and contestation, in which the consumer evidences abandonment as an imposition (something extrinsic to the choice itself). Isadora (57, psychologist) shows great irritation when commenting about campaigns which represent the cigarette as the great villain of health, saying that "it is not alone", referring to diseases like obesity which, in her opinion, is hardly discussed by society. 
Another manifestation of mourning is to list the negative consequences of the abandonment decision. Amanda (36, psychologist), for example, recounts that she developed a serious heart condition due to the stress caused by abandonment. She says that "nothing improved in my life after I stopped smoking, because as well as wanting to smoke, I had a sick heart". Although she doesn't regret abandoning cigarettes, as she perhaps "wouldn't have survived", she comments that she did not experience "this enchanted tale that people tell of recovering their sense of taste, because all that stress did me a lot of harm".

Mourning constituted one of the possibilities of establishing a distance from the positive meanings perceived in the category. Some informants at some moments also deal with this feeling by rejecting and deconstructing the advertising discourse and their own experience with the product. Thus, instead of recognizing the positive aspects of consumption they end up negating the positive repertoire associates with the category, like Amanda (36 years, psychologist) states: "I think that cigarettes don't allow people to concentrate, people become scatter-brained". Like mourning, this movement of denying benefits seems to cool positive meanings, as we can see in the following extract:

"Cigarettes do not make us seem sophisticated. When you kiss someone who smokes and you don't smoke, you kiss an ash tray! You have bad breath, it's really awful!" (Suzana, 40 years, journalist).

\section{Adopting the positive meanings of abandonment}

In various interviewees' discourses, abandonment appears as a reinforcement of self-esteem, demonstrating the psychological strength and resistance of those who have managed to overcome their addiction.

“The people I tell I've stopped smoking say: 'Congratulations', as if it were a great personal triumph. Noone really has the slightest notion of what it's like for a person who smoked like me to quit smoking. (...) It's as if I'd been through a war" (Amanda, 36 years, psychologist).

Evidence of this can be found in the way abandonment is communicated. There are frequent accounts in the interviews that reveal a commitment with this initiative through communication, due to the social control it engenders. This is what made Amanda make her abandonment process public: "Because I am very stubborn, and it would be a serious problem for me to admit defeat. So telling everyone about this was a kind of safeguard for me".

Amanda's account evidences that abandonment acquires meanings of victory and achievement and therefore starting to smoke again would be "to admit defeat". Abandonment makes the consumer gain the meanings of determination, strength and personal effort. Thus, after associating oneself with such positive meanings, taking up smoking again represents "throwing away" these qualities that have already been transferred to one's reputation.

Communication seems to seal one's commitment to the initiative and establish definitive ties with positive meanings of abandonment. Priscila (39 years, web-designer) went beyond the usual limits of this kind of communication, which is usually restricted to groups of acquaintances, when she created a blog devoted to the theme. In her blog, which receives 30 thousand visits a day, she talks about the challenges of the abandonment process, gives tips, recommends books and provides a space for interaction between participants.

Another example of creation and manipulation of positive meanings related to smoking cessation is Cristiane (29 years, economist) who decided to stop smoking for personal appearance reasons (teeth, skin, hair, nails). So she took a decision related to this abandonment to also invest in whitening her teeth: "I am going to spend some money, because if I smoke I know I'll be wasting the money I spent whitening my teeth. So this is one more action that's going to help me stop smoking".

She also recounts that she now uses the money she spent on cigarettes on weekly manicure services. As well as the commitment to the initiative (enhanced by the financial investment), Cristiane makes a positive result of abandonment tangible, given that cigarette consumption is usually 
associated with mouth diseases and yellowing of the teeth and fingers. Her abandonment, however, "does not leave marks" as its benefits are long-term ones and are almost imperceptible, because they merely avoid the problems that would be created by consumption. By whitening her teeth and manicuring her nails, Cristiane is quickly able to perceive the gains she is obtaining from the initiative.

\section{Positive meanings of social ties}

The abandonment of cigarettes was also used by various interviewees as a kind of ritual experience of reinforcing emotional ties. McCracken (1986) considers that ritual "is a kind of social action devoted to the manipulation of cultural meaning for the purpose of collective and individual categorization" (McCracken, 1986, p. 78). Antony (60, business consultant), one of the informants, offered his decision to his girlfriend on St Valentine's Day. It is also the gift Mary (42 years, philosopher) gave her father on Father's Day":

"The idea was to offer it to someone as a gift because if you offer a gift you can't take it back. My father felt very guilty because I smoked. He had already given up and he used to smoke a lot more. He was very worried about this and as he doesn't like actual gifts, I said this on a card: I've given up smoking".

For this interviewee, this gift-giving ritual helped her stick to her abandonment decision as "you can't ask someone to return a gift you've given them". The meanings of gift and reward are both present in her words. What is being offered here is not a material good but abandonment, as a sacrifice, as a commitment, something that cannot be obtained with money and thus is worth much more. Belk (2005) reminds us that, in rituals of exchange, distinctions are made between pure gifts and exchanges, between gifts and barter of commodities. The first belong to the sphere of personal relations exchanges take place in the world of commerce and impersonal relations. Mary appears to seal the absolutely intimate and special character of this relationship, where no calculations are made in terms of what is given and what is received and the value of the gift is not monetary but resides in the symbolic content it represents.

One of the interesting aspects of this initiative lies precisely in the suppression of consumption, of the merchandise. By giving her father the gift of abandonment, Mary shows that she is close to him and knows him (he doesn't like actual gifts). The initiative also brings back memories of their life together and his importance in her trajectory and, especially, the attention and care she devotes to his wellbeing, seeking to minimize his concerns. The initiative thus confers sacred status (Belk, Wallendorf, \& Sherry, 1989) on the decision in two distinct ways: (a) by evidencing the pure character of that relationship, which is not based on material goods or on the conversion of the gift offered into money; (b) by imbuing it with a transcendental character that goes beyond the ordinary, everyday sphere.

\section{Positive meanings of transformation}

Some informants used the abandonment of cigarettes in classic rites of passage like weddings, births and marriage dissolution. Rose (48 years, lawyer), one of the interviewees, said that she wanted to "cure a whole lot of things" with her separation and, for this reason, she also abandoned cigarettes. Rachel (42 years, economist) was pregnant when she decided to give up cigarettes. Although she did not have a wedding ceremony, the move to the new house and the abandonment of cigarettes served as a symbolic mark of her new status as wife and mother: "I managed to stop just like that, miraculously, I managed to stop and have never smoked since!".

Through their magical character rituals are able to produce transformation or instantaneous symbolic changes (Driver, 1991). This idea seems to be related to Rachel experience of abandonment, since the difficulty usually associated with the act of abandoning cigarettes (recognized by the interviewee herself in other situations) confers great symbolic value on her decision. Smoke cessation seems to materialize both the investment she has made in these relationships (as wife and mother) and 
the special, almost magical, character she confers on them - given that they are capable of producing miracles - making it easy for the informant to abandon cigarettes.

She herself acknowledges the symbolic importance of this decision when she describes what she felt on entering the new home: "it was so nice and pretty. I said, I'm not going to poison it, pollute it, anything like that".

Not poisoning, not polluting seem to transcend the idea of a house, encompassing more symbolic aspects like the new marriage and, above all, motherhood. The example of Rachel suggests that, similarly to consumption, abandonment is capable of serving as an evocation of what McCracken (1988, p. 104) classified as "displaced meaning". The author defines a strategy of displaced meaning as the behavior which seeks to fill the gap between the real and the ideal in social life. If certain established standards are unreal, both society and individuals can try them out, even if briefly, by purchasing products and services. According to the author, consumption is one of the ways through which culture re-establishes access to values in some intangible cases, building bridges to hope and ideals. Rachel's example suggests that abandonment can also play this role, evoking the idea of a house that does not become dirty when used, but mainly of pure relationships which do not deteriorate.

The abandonment decision, in this case, suggests the possibility of achieving an emotional state, a social position and a life-style whose materialization occurs as a consequence of abandonment - an idealized version of how life should be lived. Giving up smoking transcends functional benefits related to health to also represent a new life-style, the type of wife and mother that Rachel intends to be.

\section{Dealing with negative meanings of abandonment}

For several years now, Brazil has had a well-articulated anti-smoking policy that communicates the negative effects of cigarettes and restricts its consumption. Given its status as a socially-questioned type of consumption its abandonment usually meets with social approval, thus minimizing efforts to negotiate the negative meanings of abandonment. However, in this study I found that ex-smokers must do this in the specific contexts of sub-groups. Suzana (40 years, journalist), for example, recounts that when she meets some of her friends who still smoke she usually hears things like: "these people who don't smoke, don't have sex and don't have fun!". Abandonment of the category thus seems to mean choosing a dull, straight-laced, pleasureless life.

Among informants it was common to find a concern not to be seen as a boorish ex-smoker - a person who, based on a personal resolution, decides to impose his or her view on those who are still product consumers. Suzana (40 years, journalist) comments that "everyone knows about the consequences of smoking so it's a question of personal choice". Nancy (44 years, journalist) also states: "I didn't become a boorish ex-smoker because when I used to smoke I hated it when someone said I had to give up.... The person is tired of knowing". Rose (48 years, lawyer) also rejects nonsmokers who feel they have the right to interfere in other people's choices: "You have free choice, everyone does what they want. I am not a boorish ex-smoker".

Prohibiting consumption in closed public spaces clearly delimits spaces and minimizes negotiations between individuals (enabling the boor, i.e., the person that interferes in other people's consumption, to remain well hidden inside each of us). Antônio (60 years, business consultant) was the only one who mentioned the discomfort caused by the smell of his wife's cigarette, who kept on smoking in spite of his appeals. He confessed that he had become almost a boorish ex-smoker, emphasizing the almost as a semantic distancing from the outlawed condition of becoming someone who needs to campaign against cigarettes. As his negotiating arena is private, i.e. negotiations take place in the home, outside the reach of the law, the interviewee still has to play this role.

Some interviewees recount that they only talk about the subject when they interact with smokers regarding their abandonment process. In these situations they relive their story (in this case a source of positive associations for the ex-smoker), sharing what they have learned. The discussion moves from smoking or not smoking to how to give up smoking. This stance is clear in Mary's (42 years, 
philosopher) discourse, who, like the other interviewees, also rejects the behavior associated with the boorish ex-smoker. However, she says that she made an exception in the case of a close friend:

"I only used to speak with people I liked. I didn't become that kind of unselfish person who hands out leaflets on the street. I choose carefully. There was this guy at the university that I liked a lot, he had skin cancer, five children. And giving up was so easy for me, I'm a woman and they say that it's harder for us, but it was quite ok! I pestered this one quite a lot. But people begin not to want to see you because you seem to be the kind of person who is bringing the Messiah, people begin to avoid you. I kept quiet, left it alone".

\section{Discussion}

McCracken (1986) proposes a definition of rituals as "a kind of social action devoted to the manipulation of cultural meaning for the purpose of collective and individual categorization" (p. 78). According to the author, rituals affirm, evoke, signal or review the social order's constituent symbols and meanings, serving as tools for their manipulation. The present study contributes to a conceptual reflection about the symbolic dimension of consumption, suggesting four different types of ritual actions related to abandonment. This study suggests that through abandonment and non-consumption, individuals also create and manipulate meanings related to goods.

The interviews showed that meanings attached to consumption and non-consumption are interrelated in processes of individual and collective negotiation. The analysis sought to depict these interactions, illustrating how consumers create and manipulate the positive and negative meanings of consumption and non-consumption. The figure below highlights the movements of meanings undertaken by consumers during the category abandonment process.

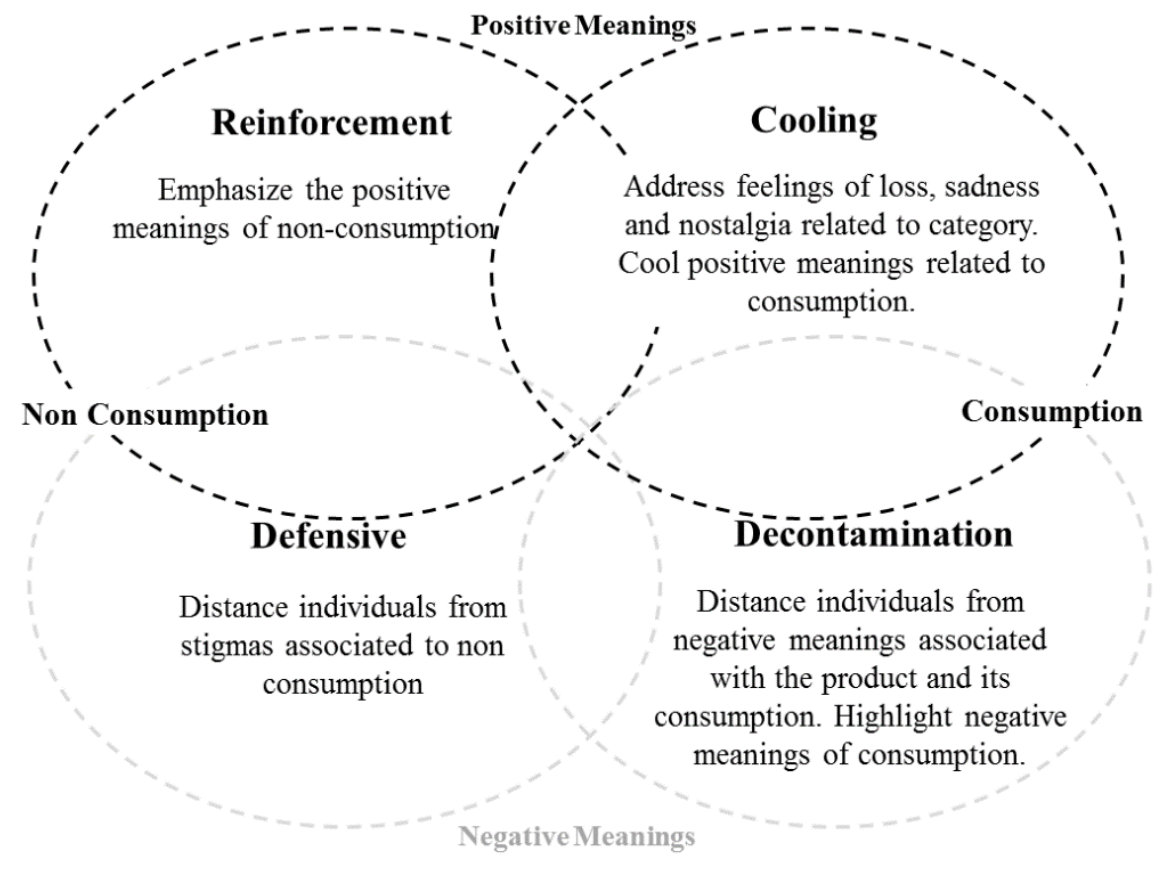

Figure 1. Movements of Creation and Manipulation of Meanings in the Abandonment Category.

The above figure contains overlapping areas, and areas that are delimited by a dotted line, thus transmitting the idea of permeability between the different sets of meanings and movements.

The function of symbolic movements is to enable consumers to make the transition from the condition of consumer to that of non-consumers - something that is not always immediate or easy, as it is necessary to subjectively and socially re-create the meanings associated with the product. 
The upper right-hand quadrant contains the cooling movements that minimize, cool or finally erase positive associations that one day led individuals to desire the product. Cooling movements are also associated with the need to address the feelings of loss and nostalgia of ex-consumers during the abandonment process.

The lower right-hand quadrant highlights decontamination movements. The abandonment of the category also articulates these symbolical acts in which individuals distance themselves from negative associations related to consumption. As suggested by Hogg and Banister (2001) and also seen in the present study, the desire not to be confused with stigmas related to the consumer constitutes an important motivation distancing oneself from the category. Through decontamination movements individuals express their distance and difference in relation to the consumer.

Both the negative aspects of consumption and the gains resulting from non-consumption can drive abandonment. The upper left-hand quadrant contains reinforcement movements that create and remind individuals of the positive meanings generated by distancing oneself from the category. They constitute symbolic movements that value the initiative, imparting a constructive meaning to abandonment.

Finally, abandonment may require the articulation of defensive movements that "protect" individuals from the negative associations related with non-consumption (lower left-hand quadrant). In the context of questioned consumptions (as in the case of cigarette consumption) such stigmas are minimized, but it is possible to perceive, even in the present study, some situations where exconsumers need to justify their choices and disentangle themselves from the negative meanings of non-consumption.

The movements described in the four quadrants do not only occur during the abandonment process and may indeed persist throughout the lives of ex-consumers, given that they continue to articulate arguments that serve to justify their choice to themselves and also socially.

\section{Final Comments}

In the marketing and consumer behavior area, this research deepens our understanding about abandonment, showing that, in addition to an indicator of new identities or social positions (Kleine \& Kleine, 2000) or a movement to distance from undesirable or negative stereotypes (Hogg \& Banister, 2001), abandonment can be offered as a connection, gift, or sacrifice that makes relations special and even magical. This aspect is not discussed in the abandonment literature and also characterizes abandonment as capable of building and communicating community.

As regards abandonment, the present study evidences the interactions and movements of positive and negative meanings related to the consumption and non-consumption of a category. The study proposes a framework that highlights the cooling, decontamination, reinforcement and defensive symbolical movements, thus constructing a tool for analyzing abandonment, offering possible paths of intervention for organizations that are interested in this issue.

Within the context of smoking cessation studies, the present study provides a contrasting viewpoint to the studies undertaken hitherto, complementing the perspectives that examine the physical or cognitive aspects of this process. It evidences that alongside the research about addiction and the effect of pharmacotherapies it is necessary to deepen our understanding of the symbolic dimension of smoking cessation.

This knowledge may have implications for public policies towards tobacco control in different ways. Several studies highlight the role of health service providers in encouraging cigarette abandonment (Aveyard et al., 2007; Fiore, 2008; Ockene et al., 2007; Rice \& Stead, 2008). This research provides material for the sensitization and training of health system professionals. Besides the 
physical difficulties related to addiction, these professionals can help patients to overcome barriers due to symbolic associations. The four quadrants offer alternative approaches in the dialogue with patients, enabling diverse arguments to be used (sometimes they can point out the dangers of smoking and on other occasions the benefits of abandonment). Multiple approaches may help to break down perceptual barriers and deal with different kinds of patients.

If we analyse, for example, Brazilian anti-smoking campaigns, we can clearly see the progress that has been achieved by the campaigns undertaken over the past 20 years. A good deal of the efforts of these campaigns, especially in the warning images that can be found on cigarette packs, have concentrated on the creation of stimuli in the lower right-hand quadrant (creation of negative meanings in consumption which motivates decontamination movements). Although it has effectively disseminated information on the product's harmful effects on health, this approach may have lost some of its power of communication due to its constant repetition over the last few decades.

The conceptual scheme proposed here point to another possible and complementary path. The analysis of the various accounts presented in this research suggests that ex-smokers become motivated to quit smoking by articulating meanings related to the gains of abandonment. Public service announcements could capture and contextualize reinforcement movements described here to renew campaigns and enrich symbolic gains related to smoking cessation. Emotional adverts were found to be more effective in encouraging quitting (National Cancer Institute, 2008). An interesting example of emotional content can be seen in Mary's history and her offering of smoking cessation as a gift to her father. It is also connected to the idea of rites of passage, like Rachel who presents smoking cessation as a symbolic mark of her new status as wife and mother.

This research also depicts how communication can seal one's commitment to the smoking cessation decision and establish ties with positive meanings of abandonment. In this context, developing initiatives that allow ex-smokers to better communicate it can invigorate this effort. The internet constitutes a promising environment for promoting abandonment through social media and online communities. Developing tools to communicate abandonment and relive the positive meanings related to it (e.g., commemorative stamps of months and years) can help ex-smokers to stick to their decision and stimulate prospects. The understanding that abandonment is able to build and encourage social connections also contributes to the development of online communities dedicated to supporting smokers in the cessation process. These forums are also aligned with the desire of ex-smokers to share what they have learned with those who wish to quit smoking. Finally, from an individual perspective, informants' strategies and symbolic movements described here might serve as inspiration for consumers seeking smoking cessation.

This research investigated symbolic aspects related to abandonment of one specific category. Cigarettes are considered a socially harmful consumption (Kwak, Zinkham, \& French, 2001) and smoking cessation is largely stimulated. Meanings created through abandonment are permeated by this social identification. It is also worth mentioning that cigarette smoking is an addictive behavior, which makes its abandonment more complex and permeated by meanings like victory, achievement, sacrifice and gift. Future research should broaden investigation about abandonment, studying positive consumption (e.g. toiletries, exercises, donation to charity, medicine) or categories that do not imply physical dependence.

\section{References}

Anderson, C. M., \& Zhu, S. H. (2007). Tobacco quitlines: looking back and looking ahead. Tobacco Control, 16(1), 81-86. doi: 10.1136/tc.2007.020701

Arnould, E. J., \& Thompson, C. J. (2005). Consumer culture theory (CCT): twenty years of research. Journal of Consumer Research, 31(4), 868-882. doi: 10.1086/426626 
Aveyard, P., Brown, K., Saunders, C., Alexander, A., Johnstone, E., Munafò, M. R., \& Murphy, M. (2007). Weekly versus basic smoking cessation support in primary care: a randomised controlled trial. Thorax, 62(10), 898-8903. doi: 10.1136/thx.2006.071837

Belk, R. W. (2005). Exchange taboos from an interpretive perspective. Journal of Consumer Psychology, 15(1), 16-21. doi: 10.1207/s15327663jcp1501_3

Belk, R. W., Wallendorf, M., \& Sherry, J. F. (1989). The sacred and the profane in consumer behavior: theodicy on the odyssey. Journal of Consumer Research, 15(1), 1-38.

Brendryen, H., \& Kraft, P. (2008). Happy ending: a randomized controlled trial of a digital multimedia smoking cessation intervention. Addiction, 103(3), 478-484. doi: 10.1111/j.13600443.2007.02119.x

Brendryen, H., Drozd, F., \& Kraft, P. (2008). A digital smoking cessation program delivered through internet and cell phone without nicotine replacement (happy ending): randomized controlled trial. Journal of Medical Internet Research, 10(5), 51. doi: 10.2196/jmir.1005

Cahill, K., Stead, L. F., \& Lancaster, T. (2011). Nicotine receptor partial agonists for smoking cessation. Cochrane Database of Systematic Reviews, 4(2), 346-347. doi: 10.1002/14651858.CD006103.pub6

Chaloupka, F. J., \& Warner, K. E. (Eds.). (1999). The economics of smoking. [Working Paper N $^{\circ}$ 7047]. National Bureau of Economic Research, Cambridge, MA. Retrieved from http://www.nber.org/papers/w7047

Chaloupka, F. J., \& Wechsler, H. (1997). Price, tobacco control policies and smoking among young adults. Journal of Health Economics, 16(3), 359-373. doi: 10.1016/S0167-6296(96)00530-9

Chapman, S. (1999). The news on tobacco control: time to bring the background into the foreground. Tobacco Control, 8(3), 237-239. doi: 10.1136/tc.8.3.237

Civljak, M., Sheikh, A., Stead, L. F., \& Car, J. (2010). Internet-based interventions for smoking cessation. Cochrane Database of Systematic Reviews, 8(9). doi: 10.1002/14651858.CD007078.pub3

Cobb, N. K., \& Graham, A. L. (2006). Characterizing internet searchers of smoking cessation information. Journal of Medical Internet Research, 8(3), 17. doi: 10.2196/jmir.8.3.e17

Cowling, D. W., Modayil, M. V., \& Stevens, C. (2010). Assessing the relationship between ad volume and awareness of a tobacco education media campaign. Tobacco Control, 19(1), 37-42. doi: $10.1136 /$ tc. 2009.030692

Driver, T. (1991). The magic of ritual. New York: HarperCollins.

Fiore, M. (2008). Treating tobacco use and dependence: 2008 update: clinical practice guideline. Darby: DIANE Publishing.

Gaskell, G., \& Bauer, M. W. (2002). Para uma prestação de contas públicas: além da amostra, da fidedignidade e da validade In M. W. Bauer \& G. Gaskell (Orgs.), Pesquisa qualitativa com texto, imagem e som: um manual prático (pp. 470-490). Petrópolis: Vozes.

Hogg, M. K. (1998). Anti-constellations: exploring the impact of negation on consumption. Journal of Marketing Management, 14(1-3), 133-158. doi: 10.1362/026725798784959354

Hogg, M. K., \& Banister, E. N. (2001). Dislikes, distastes and the undesired self: conceptualizing and exploring the role of the undesired end state in consumer experience. Journal of Marketing Management, 17(1), 73-104. doi: 10.1362/0267257012571447 
Hogg, M. K., Banister, E. N., \& Stephenson, C. A. (2009). Mapping symbolic (anti)-consumption. Journal of Business Research, 62(2), 148-159. doi: 10.1016/j.jbusres.2008.01.022

Hopkins, D. P., Briss, P. A., Ricard, C. J., Husten, C. G., Carande-Kulis, V. G., Fielding, J. E., Alao, M. O., McKenna, J. W., Sharp, D. J., Harris, J. R., Woollery, T. A., Harris, K. W., \& Task Force on Community Preventive Services. (2001). Reviews of evidence regarding interventions to reduce tobacco use and exposure to environmental tobacco smoke. American Journal of Preventive Medicine, 20(2), 16-66. doi: 10.1016/S0749-3797(00)00297-X

Hughes, J. R., Stead, L. F., \& Lancaster, T. (2007). Antidepressants for smoking cessation. Cochrane Database of Systematic Reviews, 24(1), 1-123. doi: 10.1002/14651858.CD000031.pub3

Kleine, R. E., \& Kleine, S. S. (2000). Consumption and self-schema changes throughout the identity project life cycle. Advances in Consumer Research, 27(1), 279-285.

Kwak, H., Zinkham, G. M., \& French, W. A. (2001). Moral orientation: its relation to product involvement and consumption. Advances in Consumer Research, 28(1), 431-436.

Levy, D., Almeida, L. M., \& Szklo, A. (2012). The Brazil simsmoke policy simulation model: the effect of strong tobacco control policies on smoking prevalence and smoking-attributable deaths in a middle income nation. PLoS Medicine, 9(11), 1-12. doi: 10.1371/journal.pmed.1001336

Li, J., \& Grigg, M. (2009). New Zealand: new graphic warnings encourage registrations with the quitline. Tobacco Control, 18(1), 72. doi: 10.1136/tc.2008.027649.

Malone, R. E., Boyd, E., \& Bero, L. A. (2000). Science in the news: journalists' constructions of passive smoking as a social problem. Social Studies of Science, 30(5), 713-735. doi: $10.1177 / 030631200030005003$

Martire, K. A., Mattick, R. P., Doran, C. M., \& Hall, W. D. (2011). Cigarette tax and public health: what are the implications of financially stressed smokers for the effects of price increases on smoking prevalence? Addiction, 106(3), 622-630. doi: 10.1111/j.1360-0443.2010.03174.x

McCracken, G. (1986). Culture and consumption: a theoretical account of the structure and movement of the cultural meaning of consumer goods. Journal of Consumer Research, 13(1), 71-84. doi: $10.1086 / 209048$

McCracken, G. (1988). Culture and consumption: new approaches to the symbolic character of consumer goods and activities. Bloomington: Indiana University Press.

Miles, M. B., \& Huberman, M. (1994). Qualitative data analysis: an expanded source book. Thousand Oaks, CA: Sage.

Miller, C. L., Hill, D. J., Quester, P. G., \& Hiller, J. E. (2009). Impact on the Australian Quitline of new graphic cigarette pack warnings including the Quitline number. Tobacco Control, 18(3), 235-237. doi: 10.1136/tc.2008.028290

Miller, C. L., Wakefield, M., \& Roberts, L. (2003). Uptake and effectiveness of the Australian telephone Quitline service in the context of a mass media campaign. Tobacco Control, 12(Suppl. 2), 53-58. doi: 10.1136/tc.12.suppl_2.ii53

Ministério da Saúde. (2012). Vigitel Brasil 2011: Vigilância de Fatores de Risco e Proteção para Doenças Crônicas por Inquérito Telefônico. Brasília: autor. Retrieved from http://bvsms.saude.gov.br/bvs/publicacoes/vigitel_brasil_2011_fatores_risco_doencas_cronicas. pdf

National Cancer Institute. (2008). The role of the media in promoting and reducing tobacco use. Retrieved from http://cancercontrol.cancer.gov/BRP/tcrb/monographs/19/m19_complete.pdf 
Ockene, J. K., Edgerton, E. A., Teutsch, S. M., Marion, L. N., Miller, T., Genevro, J. L., LovelandCherry, C. J., Fielding, J. E., \& Briss, P. A. (2007). Integrating evidence-based clinical and community strategies to improve health. American Journal of Preventive Medicine, 32(3), 244252. doi: 10.1016/j.amepre.2006.11.007

Pechmann, C., Biglan, A., Grube, J. W., \& Cody, C. (2012). Transformative consumer research for addressing tobacco and alcohol. In D. G. Mick, S. Pettigrew, C. C. Pechmann, \& J. L. Ozanne (Eds.), Transformative consumer research for personal and collective well-being (pp. 353-390). New York: Routledge.

Projeto ITC. (2009). Projeto internacional de avaliação das políticas de controle do tabaco: ITC Brasil: resumo. Retrieved from http://www.obid.senad.gov.br/portais/OBID/biblioteca/documentos/328944.pdf

Rabius, V., Pike, K. J., Wiatrek, D., \& McAlister, A. L. (2008). Comparing internet assistance for smoking cessation: 13-month follow-up of a six-arm randomized controlled trial. Journal of Medical Internet Research, 10(5), 45. doi: 10.2196/jmir.1008

Rice, V. H., \& Stead, L. F. (2008). Nursing interventions for smoking cessation. Cochrane Database of Systematic Reviews, (1), 1-58. doi: 10.1002/14651858.CD001188.pub3

Rook, D. W. (1985). The ritual dimension of consumer behavior. Journal of Consumer Research, 12(3), 251-265.

Rook, D. W. (2006). Let's pretend: projective methods reconsidered. In R. W. Belk (Ed.), Handbook of qualitative research methods in marketing (pp.143-155). Cheltenham: Edward Elgar.

Roster, C. A. (2001). Letting go: the process and meaning of dispossession in the lives of consumers. Advances in Consumer Research, 28(1), 425-430.

Scollo, M., Younie, S., Wakefield, M., Freeman, J., \& Icasiano, F. (2003). Impact of tobacco tax reforms on tobacco prices and tobacco use in Australia. Tobacco Control, 12(Suppl. 2), 59-66. doi:10.1136/tc.12.suppl_2.ii59

Sheffer, M. A., Redmond, L. A., Kobinsky, K. H., Keller, P. A., McAfee, T., \& Fiore, M. C. (2010). Creating a perfect storm to increase consumer demand for Wisconsin's Tobacco Quitline. American Journal of Preventive Medicine, 38(3), 343-346. doi: 10.1016/j.amepre.2009.11.014

Shiffman, S., Brockwell, S. E., Pillitteri, J. L., \& Gitchell, J. G. (2008). Use of smoking-cessation treatments in the United States. American Journal of Preventive Medicine, 34(2), 102-111. doi: 10.1016/j.amepre.2007.09.033

Siahpush, M., Wakefield, M. A., Spittal, M. J., Durkin, S. J., \& Scollo, M. M. (2009). Taxation reduces social disparities in adult smoking prevalence. American Journal of Preventive Medicine, 36(4) 285-291. doi: 10.1016/j.amepre.2008.11.013

Slater, D. (2002). Consumer culture \& modernity. Oxford: Blackwell.

Stead, L. F., Perera, R., Mant, D., \& Lancaster, T. (2008). Nicotine replacement therapy for smoking cessation. Database of Systematic Reviews, 23(1). CD000146 doi: 10.1002/14651858.CD000146.pub3

Strauss, A., \& Corbin, J. (2008). Pesquisa qualitativa: técnicas e procedimentos para o desenvolvimento de teoria fundamentada. Porto Alegre: Artmed.

Suarez, M., Chauvel, M. A., \& Casotti, L. (2012). Motivações e significados do abandono de categoria: aprendizado a partir da investigação com ex-fumantes e ex-proprietários de automóveis. Cadernos EBAPE. BR, 10(2), 411-434. doi: 10.1590/S1679-39512012000200010 
Thompson, C. J., Pollio, H. R., \& Locander, W. B. (1994). The spoken and the unspoken: a hermeneutic approach to understanding the cultural viewpoints that underlie consumers' expressed meanings. Journal of Consumer Research, 21(3), 432-452. doi: 10.1086/209409

West, R., DiMarino, M. E., Gitchell, J., \& McNeill, A. (2005). Impact of UK policy initiatives on use of medicines to aid smoking cessation. Tobacco Control, 14(3), 166-171. doi: $10.1136 /$ tc. 2004.008649

Willemsen, M. C., Simons, C., \& Zeeman, G. (2002). Impact of the new EU health warnings on the Dutch quit line. Tobacco Control, 11(4), 381-382. doi: 10.1136/tc.11.4.381

World Health Organization. (2013). Tabaco. Retrieved from http://www.who.int/mediacentre/factsheets/fs339/en/index.html

Young, M. M. (1991). Disposition of possessions during role transitions. Advances in Consumer Research, 18(1), 33-39.

Zhu, S.-H., Lee, M., Zhuang, Y.-L., Gamst, A., \& Wolfson, T. (2012). Interventions to increase smoking cessation at the population level: how much progress has been made in the last two decades? Tobacco Control, 21(2), 110-118. doi: 10.1136/tobaccocontrol-2011-050371 